\title{
Analisis Pasokan Komoditi Unggulan Pada Pengembangan Wilayah di Kabupaten Jeneponto
}

\section{Supply Analysis of Leading Commodities in Regional Development in Jeneponto District}

\author{
E.A. Karimeng ${ }^{1}$, Murshal Manaf ${ }^{2}$, Agus Salim² \\ ${ }^{1}$ Magister Perencanaan Wilayah dan Kota Program Pascasarjana Universitas Bosowa \\ ${ }^{2}$ Program Studi Perencanaan Wilayah dan Kota, Program Pascasarjana, Universitas Bosowa \\ E-mail: karimeng62@gmail.com
}

Diterima: 20 Februari 2019/Disetujui 07 Juni 2019

\begin{abstract}
Abstrak. Pengembangan wilayah sebagai konsekwensi atas berbagai faktor unggulan disuatu wilayah, Kabupaten Jeneponto sebagai wilayah studi memiliki komoditas unggulan dari berbagai komoditas yang ada, yaitu komoditas disector perkebunan palawija, salahsatu unggulan jenis tanaman palawija adalah tanaman jagung. Rumusan masalah yaitu bagaimana pengaruh jarak dan waktu tempuh terhadap distribusi dari asal kepemasaran, bagaimana komoditas unggulan, dan komparasi jenis komoditas unggulan terhadap pengembangan wilayah. Tujuan penelitian adalah menganalisis pengaruh jarak tempuh, komoditas unggulan dan komparasi unggulan jenis palawija terhadap pengembangan wilayah. Jenis penelitian merupakan deskriptif analisis kualitatif melalui jawaban responden yang diambil diwilayah penelitian yaitu di Kecamatan, Binamu, Batang dan Arungkeke di Kabupaten Jeneponto selanjutnya tabulasi data diproses dengan menggunakan software Regresi linear Berganda dan metodep rosentase. Hasil pembahasan yaitu bahwa ketiga variabel jarak tempuh, jenis komoditas unggulan dan komparasi unggulan memiliki pengaruh terhadap pengembangan dan model regresi yang diperoleh yaitu $\mathrm{Y}=0,186+0,420 . \mathrm{X} 2+0,531 . \mathrm{X} 3(\mathrm{R} 2=0,924)$. Berdasarkan persamaan model pada pengembangan wilayah masyarakat memberikan respon sebesar 58 dari 100 atau 58\% responden menyatakan berpengaruh, 69 atau $69 \%$ mengetahui komoditas unggulan untuk pengembangan wilayah di Kabupaten dan 54 dari 100 atau 54\% mengetahui jagung sebagai unggulan komparatif di Kabupaten Jeneponto
\end{abstract}

Kata Kunci: Guna Lahan, Kependudukan, Aksesibilitas, Permaalahan, Perkotaan

\begin{abstract}
Regional development as a consequence of various superior factors in one region, Jeneponto Regency as the study area of having superior commodities from various existing commodities, namely commodity of vegetable crops, one of the main types of crops is corn. The formulation of the problem is how the influence of distance and travel time on the distribution of the origin of the market, how the commodities are superior, and the comparison of the types of superior commodities to the development of the region. The purpose of the study was to analyze the effect of mileage, superior commodities and superior comparability of secondary crops on regional development. This type of research is descriptive qualitative analysis through the answers of respondents taken in the research area, namely in Districts, Binamu, Batang and Arungkeke in Jeneponto Regency, then tabulation of data is processed using Multiple Linear Regression software and percentage method. The results of the discussion are that the three variables of distance, the types of superior commodities and superior comparability have an influence on the development and regression models obtained, namely $Y=0.186+$ $0.420 . X 2+0.531 . X 3(R 2=0.924)$. Based on the model equation on community development, the response was 58 out of 100 or $58 \%$ of respondents said that influential, 69 or $69 \%$ knew of superior commodities for regional development in the Regency and 54 out of 100 or 54\% knew that corn was a comparative superiority in Jeneponto Regency.
\end{abstract}

Keywords: Land Use, Population, Accessibility, Problem, Urban

\section{Pendahuluan}

Pembangunan daerah sangat strategis dalam kerangka pelaksanaan pembangunan nasional, bukan hanya membangun daerah sebagai bagian integral pembangunan nasional, tetapi berhasil mendorong peningkatan pemerataan, stabilitas, pertumbuhan, dan kesejahteraan masyarakat sebagai pelaku utama pembangunan. Pembangunan ekonomi suatu daerah dapat diukur melalui pertumbuhan ekonomi, yang sekaligus indikator tersebut memberikan gambaran tentang sejauh mana aktivitas perekonomian daerah pada periode tertentu dan telah menghasilkan peningkatan pendapatan bagi masyarakat yang ditunjukkan dengan peningkatan pendapatan per kapita.

Pertumbuhan ekonomi daerah pada dasarnya dipengaruhi oleh potensi ekonomi yang dimiliki oleh daerah tersebut. Oleh karena itu, pemanfaatan dan pengembangan potensi ekonomi menjadi prioritas utama yang harus digali dan dikembangkan dalam melaksanakan pembangunan ekonomi daerah secara berkelanjutan, terutama semenjak ditetapkannya otonomi daerah (UU No.22/1999). Terkait dengan Otonomi Daerah, pengembangan sektor ekonomi unggulan dapat merupakan strategi yang efektif dalam pengembangan ekonomi daerah 
karena dianggap bahwa suatu daerah yang menerapkannya akan relatif lebih mandiri dalam pengembangan ekonomi serta lebih siap dalam menghadapai era persaingan yang tidak hanya bersifat lokal tetapi juga bersifat global, (Elmi, 2003).

Selain itu, pengembangan sektor ekonomi unggulan dianggap dapat menjadi solusi terhadap berbagai masalah yang dihadapi daerah dalam melaksanakan pembangunan ekonominya, seperti masalah kemiskinan, pengangguran, kesenjangan antar wilayah (Takahashi, 2003; Kusman, 2012), dan rendahnya penerimaan daerah dari PAD (Desembriarto, 2000; Sjoholm, 1999). Oleh karena itu, kemampuan pemerintah daerah untuk melihat sektor yang memiliki keunggulan di wilayahnya menjadi semakin penting, sektor yang mempunyai keunggulan memiliki prospek yang lebih baik untuk dikembangkan dan diharapkan dapat mendorong sektor-sektor lain untuk berkembang (Tarigan, 2005).

Wilayah pengembangan adalah pewilayahan untuk tujuan pembangunan/development. Tujuan-tujuan pembangunan terkait dengan lima kata kunci, yaitu: (1) pertumbuhan; (2) penguatan keterkaitan; keberimbangan; (4) kemandirian; dan (5) keberlanjutan.

Pembangunan merupakan upaya yang sistematik dan berkesinambungan untuk menciptakan keadaan yang dapat menyediakan berbagai alternatif yang sah bagi pencapaian aspirasi setiap warga yang paling humanistik. Sedangkan menurut Anwar (2012), pembangunan wilayah dilakukan untuk mencapai tujuan pembangunan wilayah yang mencakup aspek-aspek pertumbuhan, pemerataan dan keberlanjutan yang berdimensi lokasi dalam ruang dan berkaitan dengan aspek sosial ekonomi wilayah.

Pengertian pembangunan dalam sejarah dan strateginya telah mengalami evolusi perubahan, mulai dari strategi pembangunan yang menekankan kepada pertumbuhan ekonomi, kemudian pertumbuhan dan kesempatan kerja, pertumbuhan dan pemerataan, penekanan kepada kebutuhan dasar (basic need approach), pertumbuhan dan lingkungan hidup, dan pembangunan yang berkelanjutan (suistainable development). Sedangkan konsep wilayah perencanaan adalah wilayah yang dibatasi berdasarkan kenyataan sifat-sifat tertentu pada wilayah tersebut yang bisa bersifat alamiah maupun non alamiah yang sedemikian rupa sehingga perlu direncanakan dalam kesatuan wilayah perencanaan.

Menurut Alkadri (2001) pengembangan adalah kemampuan yang ditentukan oleh apa yang dapat dilakukan dengan apa yang dimiliki untuk meningkatkan kualitas hidup. Kata pengembangan identik dengan keinginan menuju perbaikan kondisi disertai kemampuan untuk mewujudkannya. Pendapat lain bahwa pengembangan adalah suatu proses untuk mengubah potensi yang terbatas sehingga mempengaruhi timbulnya potensi yang baru, dalam hal ini termasuk mencari peluang yang ada dalam kelompok-kelompok yang berbeda yang tidak semuanya mempunyai potensi yang sama (Budiharsono, 2002).

Pada dasarnya pengembangan wilayah harus disesuaikan dengan kondisi, potensi dan permasalahan wilayah yang bersangkutan (Riyadi dalam Ambardi dan Socia, 2002).

Dalam Undang-Undang Nomor 26 tahun 2007 tentang Penataan Ruang, wilayah adalah ruang yang merupakan kesatuan geografis beserta segenap unsur yang terkait kepadanya yang batas dan sistemnya ditentukan berdasarkan aspek administratif dan atau aspek fungsional.

Konsep wilayah yang paling klasik (Hagget, Cliff dan Frey, 1977 dalam Rustiadi et al., 2011) mengenai tipologi wilayah, mengklasifikasikan konsep wilayah ke dalam tiga kategori, yaitu: (1) wilayah homogen (uniform/homogenous region); (2) wilayah nodal (nodal region); dan (3) wilayah perencanaan (planning region atau programming region).

Tujuan pengembangan wilayah mengandung 2 (dua) sisi yang saling berkaitan yaitu sisi sosial dan ekonomis. Dengan kata lain pengembangan wilayah adalah merupakan upaya memberikan kesejahteraan dan meningkatkan kualitas hidup masyarakat, misalnya menciptakan pusat-pusat produksi, memberikan kemudahan prasarana dan pelayanan logistik dan sebagainya (Triutomo, 2001).

Pengembangan wilayah sangat dipengaruhi oleh komponen-komponen tertentu seperti (Friedman \& Allonso, 2008): a) Sumber daya lokal, merupakan kekuatan alam yang dimiliki wilayah tersebut seperti lahan pertanian, hutan, bahan galian, tambang dan sebagainya. Sumber daya lokal harus dikembangkan untuk dapat meningkatkan daya saing wilayah tersebut, b) Pasar, merupakan tempat memasarkan produk yang dihasilkan suatu wilayah sehingga wilayah dapat berkembang, c) Tenaga kerja, berperan dalam pengembangan wilayah sebagai pengolah sumber daya yang ada, d) Investasi, semua kegiatan dalam pengembangan wilayah tidak terlepas dari adanya investasi modal. Investasi akan masuk ke dalam suatu wilayah yang memiliki kondisi kondusif bagi penanaman modal, e)

Kemampuan pemerintah, pemerintah merupakan elemen pengarah pengembangan wilayah. Pemerintah yang berkapasitas akan dapat mewujudkan pengembangan wilayah yang efisien karena sifatnya sebagai katalisator pembangunan, f) Transportasi dan Komunikasi, berperan sebagai media pendukung yang menghubungkan wilayah satu dengan wilayah lainnya. Interaksi antara wilayah seperti aliran barang, jasa dan informasi akan sangat berpengaruh bagi tumbuh kembangnya suatu wilayah, dan g) Teknologi, kemampuan teknologi berpengaruh terhadap pemanfaatan sumber daya wilayah melalui peningkatan output produksi dan keefektifan kinerja sektor-sektor perekonomian wilayah.

Pengembangan wilayah adalah upaya pembangunan dalam suatu wilayah administratif atau kawasan tertentu agar tercapai kesejahteraaan (people property) melalui pemanfaatan peluang-peluang dan pemanfaatan sumber daya secara optimal, efisien, sinergi dan berkelanjutan dengan cara menggerakkan kegiatan-kegiatan ekonomi, penciptaan iklim kondusif, perlindungan lingkungan dan penyediaan prasarana dan sarana. Pada dasarnya komponen utama untuk mencapai kesejahteraan masyarakat dalam suatu wilayah adalah kemajuan ekonomi wilayah bersangkutan.

Menurut Martin (2009), kinerja ekonomi suatu wilayah dan kemampuannya untuk tumbuh dan berkembang dipengaruhi oleh berbagai faktor yang berbeda. Faktor-faktor ini mungkin berbeda ke lokasi, seperti dukungan sumber daya alam, atau bisa menjadi hasil dari peristiwa masa lalu, seperti investasi atau pola migrasi. Lima faktor kunci pembangunan ekonomi jangka panjang daerah adalah: Modal manusia , terutama pendidikan dan keterampilan, berkelanjutan (ekonomi, 
lingkungan dan sosial) masyarakat dan pertumbuhan penduduk, akses ke pasar regional internasional, nasional dan, keunggulan komparatif dan daya saing bisnis, dan kemitraan lintas sektoral dan antar pemerintah yang efektif (termasuk melalui pendekatan berbasis tempat) dan terpadu daerah berencana.

Faktor penentu tersebut tidak beroperasi secara independen. Kegiatan untuk mempengaruhi salah satu penentu juga akan berdampak pada yang lain. Misalnya, menarik warga terampil untuk suatu kawasan akan berdampak pada pertumbuhan penduduk serta modal manusia kawasan. Demikian pula, mengembangkan hubungan perdagangan antar kawasan meningkatkan akses ke pasar dan juga mempromosikan daya saing usaha.

Pendekatan teknis kewilayahan melalui pendekatan homogenitas atau system fungsional mengalami proses yang lebih kompleks karena pelaksanaannya meliputi aspek kesepakatan atau komitmen para aktor regional dalam memadukan kekuatan endogen (Abdurrahman, 2005). Salah satu bentuk konsep ini adalah wilayah agropolitan yang dirancang pertama kali oleh Friedman, Mc Dauglas, 1978 yang merupakan rancangan pembangunan dari bawah (development from below) sebagai reaksi dari pembangunan top down (development from above). Agropolitan merupakan distrik atau region selektif yang dirancang agar pembangunan digali dari jaringan kekuatan lokal ke dalam yang kuat baru terbuka keluar (Sugiono, 2002). Namun dimensi ruang (spatial) memiliki arti yang penting dalam konteks pengembangan wilayah, karena ruang dapat menciptakan konflik dan pemicu kemajuan bagi individu dan masyarakat. Secara kuantitas ruang adalah terbatas dan secara kualitas ruang memiliki karakteristik dan potensi yang berbeda-beda. Maka dari itu intervensi terhadap kekuatan pasar (planning) yang berwawasan keruangan memegang peranan yang sangat penting dalam formulasi kebijakan pengembangan wilayah. Sehingga keserasian berbagai kegiatan pembangunan sektor dan wilayah dapat diwujudkan, dengan memanfaatan ruang dan sumber daya yang ada didalamnya guna mendukung kegiatan kehidupan masyarakat (Riyadi dalam Ambardi, 2002). Sebagai suatu sistem yang kompleks perlu intervensi isolasi dalam proses integrasi kedalam dengan kontrol dan subsidi yang mencegah proses infiltrasi dari luar (Sugiono, 2002). Namun karena penerapan program agropolitan yang berjalan seiring dengan proses globalisasi maka proteksi wilayah sulit dilakukan. Jadi ada dua sisi yang saling tarik menarik dan keduanya juga saling bertolak belakang. Di mana satu sisi dibutuhkan kemandirian dalam pengembangkan wilayah sementara disisi lainnya dibutuhkan proteksi atau kekuatan central agar satu dan lain hal dapat dikondisikan untuk mencapai tujuan yang ideal. Sementara itu hal lain yang juga berpengaruh besar adalah adanya kekuatan globalisasi yang tidak memungkinkan bagi pemerintah untuk mengatur segala sesuatunya sesuai dengan konsep yang dicanangkan. Ada beberapa perubahan yang terjadi sesuai dengan berjalannya proses pembangunan itu sendiri.

Salah satu sektor ekonomi unggulan yang memiliki prospek untuk dikembangkan dan diharapkan dapat mendorong sektor-sektor lain untuk berkembang di berbagai wilayah (Brata, 2002). Kabupaten Jeneponto merupakan wilayah yang memiliki sektor pertanian yang cukup luas. Sektor pertanian yang tergolong strategis dalam menunjang pembangunan ekonomi daerah di Kabupaten Jeneponto adalah tanaman jagung, karena Kabupaten Jeneponto merupakan salah satu pemasok jagung terbesar di Sulawesi Selatan dengan luas panen jagung 47.955 hektar dan rata-rata produksi sebesar 271.074 ton (BPS, 2017). Di sisi lain, besarnya produksi jagung di Kabupaten Jeneponto tersebut tidak sekaligus membuat petani sejahtera dan berkembanya wilayah, karena berdasarkan data Statistik Propinsi Sulawesi Selatan tahun 2014, Kabupaten Jeneponto merupakan salah satu kabupten yang jumlah penduduk miskin yang tinggi yakni 54,15 ribu orang atau sekitar 15,33 \% dari jumlah penduduk yang mencapai 353.287 orang.

Pembangunan dan pengembangan komoditi jagung di Kabupaten Jeneponto masih menghadapi sejumlah kendala, diantaranya adalah masih rendahnya pendapatan petani, harga komoditi jagung yang berfluktuasi, lemahnya posisi tawar petani terhadap pembeli, dan terbatasnya sarana serta akses pemasaran petani ke pembeli. Pada sisi lain, agribisnis jagung di kabupaten Jeneponto masih menerapkan sistem yang tersekat-sekat, masing-masing subsistem saling berdiri sendiri sebagai akibat dari konsep agribisnis (beserta manfaat-manfaatnya) yang belum sepenuhnya diterapkan secara benar dalam perencanaan perekonomian daerah, dan para pembuat kebijakan juga seringkali dihadapkan pada kerumitan dan lingkup pengambilan keputusan sehubungan aktivitas dari agribisnis jagung yang kompleks dan melibatkan banyak pelaku. Praktik-praktik agribisnis jagung yang terjadi selama di Kabupaten Jeneponto, tidak adanya keseinmbangan antara penawaran (produksi) dan permintaan sehingga sering terjadi fluktuasi harga pasar. Secara umum produksi jagung di Kabupaten Jeneponto. belum melihat apa yang dibutuhkan pasar, penanaman jagung dilakukan secara serempak oleh para petani diberbagai wilayah kecamatan (kecamatan Tiroang, Kelara, Bangkala, dan Arung Keke. Binamu, Rumbia, Turatea, Tarowang, Kelara, Batang, Bontoramba, dan Tamalate), sehingga waktu panen juga dilakukan secara bersamaan. Akibat panen yang bersamaan, komoditi jagung di saat itu berlimpah di pasaran (over supply) dan langsung berimplikasi pada jatuhnya harga.

Dalam situasi permasalahan pada komoditi jagung di Kabupaten Jeneponto tersebut, perbaikannya dapat dicapai jika rantai pasokan yang optimal dapat diterapkan (Tajidan.et.al,2013). Menurut Chaudhuri (2010) optimalisasi pada praktek rantai pasokan komoditi pertanian adalah sangat krusial untuk meningkatkan pendapatan petani dan mengurangi tingginya proporsi petani yang hidup dalam kemiskinan di suatu wilayah. Hausman (2004) menyarankan bahwa untuk perbaikan praktek rantai pasokan dengan wilayah sentra produksi yang tersebar, maka sangat penting untuk mempertimbangkan masalah yang terkait dengan faktor jarak tempuh, keunggulan komparatif dan integrasi rantai pasokan.

Sudah banyak penelitian dilakukan untuk mempelajari praktek rantai pasokan pada komodi jagung, misalnya Taji, et.al, (2013) di Nusa Tenggara Timur, Indonesia; Heyman 
dan Saosaovaphak (2012) di Myanmar; dan Katwal (2007) di Bhutan; namun penelitian sebelumnya tersebut pada umumnya hanya memfokuskan pada keterkaitan antara praktek rantai pasokan jagung dengan konteks kinerja organisasi; dan hingga kini masih sangat langka penelitian yang khusus mengkaji tentang keterkaitan antara praktek rantai pasokan komoditi jagung dengan konteks pengembangan wilayah (Banarjee, 2004), apalagi komoditi jagung memegang peranan penting bagi perekonomian suatu wilayah sentra produksi seperti di kabupaten Jeneponto yang dikatagorikan sebagai kabupeten tertinggal. Jagung di Kabupaten Jeneponto merupakan komoditi pangan terpenting ke dua setelah padi/beras, serta sebagai sumber pendapatan dan lapangan kerja bagi penduduk, juga sebagai komoditi tradable yang dapat menghasilkan retribusi untuk pendapatan bagi daerah. Oleh karena itu, penelitian untuk menganalisis praktek rantai pasokan yang optimal pada komoditi jagung dan pengaruhnya terhadap pengembangan wilayah di Kabupaten Jeneponto penting untuk dilakukan.

Tujuan penelitian adalah untuk menganalisis pengaruh faktor jarak tempuh, komditas unggulan dan komparasi komditas unggulan terhadap pengembangan wilayah kabupaten dan model regresi faktor jarak tempuh, komoditas unggulan dan komparasi komoditas unggulan terhadap pengembangan wilayah kabupaten.

\section{Metode Penelitian}

\section{a. Pendekatan Penelitian}

Penelitian ini termasuk dalam pendekatan deskriptif kualitatif, maka jenis data yang digunakan terdiri dari data kualitatif. Data kualitatif adalah data yang berupa keterangan atau kata-kata biasa, sedangkan data kuantitatif adalah data yang berupa angka. Di samping itu, berdasarkan cara memperolehnya, penelitian ini menggunakan data primer dan data sekunder. Data primer adalah data yang diperoleh langsung dari responden, dan data sekunder diperoleh dari kepustakaan (hasil-hasil penelitian dan kajian sebelumnya) dan dokumen kebijakan (program) yang berhubungan dengan masalah penelitian, yang juga berguna untuk melengkapi data yang diperoleh dari hasil kuesioner.

Lokasi penelitian di Kecamatan Binamu, Taroang dan Kecamatan Arungkeke Kabupaten Jeneponto, Provinsi Sulawesi Selatan. Daerah kecamatan tersebut dipilih secara sengaja dengan kriteria : (1) sebagai salah satu kawasan strategis untuk pengembangan komoditi jagung dan (2) mememiliki pontensi luas lahan yang besar sebagai daerah pengembangan komoditi jagung dimasamasa mendatang (Dinas Pertanian Kabaupaten Jeneponto, 2011).

\section{b. Populasi dan Sampel}

Ppopulasi dan sasaran penelitian ini adalah para pelaku dari rantai pasokan komoditi jagung yakni distributor saprodi, petani/kelompok tani, pedagang pengumpul kecil, pedagang pengumpul besar, mengingat ukuran populasinya tidak diketahui dengan pasti dan keberadaannya tersebar secara geografis, maka teknik pengambilan sampel yang digunakan adalah Snowball sampling yaitu mewawancarai responden yang berjumlahnya sedikit, kemudian mewawancarai responden lainnya berdasarkan rekomendasi atau informasi dari responden awal, terus menerus sehingga jumlahnya bertambah banyak hingga informasi yang diperoleh dirasa cukup.

\section{Hasil dan Pembahasan}

Penelitian ini menggunakan model penelitian kualitatif. Penelitian kualitatif bertujuan memperoleh gambaran seutuhnya mengenai suatu hal menurut pandangan manusia yang diteliti. Penelitian kualitatif berhubungan dengan ide, persepsi, pendapat, atau kepercayaan orang yang diteliti; kesemuanya tidak dapat diukur dengan angka (Basuki, 2006).

a. Uji Linearitas

Uji linearitas merupakan pengujian yang bertujuan untuk mengetahui apakah regresi bersifat linier ataukah tidak.Uji linearitas dalam penelitian ini menggunakan tabel ANOVA variabel $\mathrm{X}$ dan $\mathrm{Y}$ dari nilai signifikan. Apabila nilai signifikan dari tabel ANOVA $<0,05$, maka dapat disimpulkan bahwa hubungan variabel $\mathrm{x}$ dan $\mathrm{y}$ bersifat linier. Uji linieritas dalam penelitian ini menggunakan SPSS v.21.dengan hasil pengujian sebagai berikut.

Tabel 1 Pengujian Linearitas (SPSS)

\begin{tabular}{l|c|c|c|c|c}
\hline \multicolumn{1}{c|}{ Model } & $\begin{array}{c}\text { Sum of } \\
\text { Squares }\end{array}$ & df & $\begin{array}{c}\text { Mean } \\
\text { Square }\end{array}$ & F & Sig. \\
\hline Regression & 44.262 & 3 & 14.754 & 429.433 & $.000^{\mathrm{b}}$ \\
Residual & 3.298 & 96 & .034 & & \\
\hline \multicolumn{7}{c}{ Total } & 47.560 & 99 & & & \\
\hline \\
b. Dependent Variable: Y Predictors: (Constant), X1, X2, X3
\end{tabular}

Berdasarkan Tabel 1 tersebut dapat dilihat bahwa nilai signifikan dari tabel ANOVA sebesar 0,000., kurang dari nilai signifikan $0,05(0,000<0,05)$, yang artinya adalah hubungan variabel $\mathrm{Y}$ dan semua variabel $\mathrm{X}$ bersifat linear

\section{b) Uji Korelasi}

Metode ini dimaksudkan untuk melihat hubungan antara variabel bebas dengan variabel tidak bebas dan antar sesama variabel bebas. Jika antar variabel bebas mempunyai nilai korelasi > 0,5, maka salah satu dari variable bebas tersebut dihapuskan karena sudah saling mewakili satu sama lain. Untuk mengetahui variabel bebas apa yang dihapuskan, maka dilihat hubungan variabel bebas dan variabel tidak bebas yang mempunyai nilai korelasi lebih besar dengan variabel tidak bebas harus dipertahankan. Bentuk penilaian dapat dilihat pada Tabel 2.

Tabel 2. Interpretasi nilai $\mathrm{r}$

\begin{tabular}{c|c}
\hline $\mathrm{r}$ & Interpretasi \\
\hline $0,00-0,19$ & Sangat rendah \\
$0,20-0,39$ & Rendah \\
$0,40-0,59$ & sedang \\
$0,60-0,79$ & Tinggi \\
$0,80-1,00$ & Sangat tinggi \\
\hline Sumber $:$ Prof. Dr. Jogiyant
\end{tabular}

Sumber : Prof. Dr. Jogiyanto HM, MBA,Akt. (2011).

c. Uji Koefisien Regresi Parsial t-test)

Untuk mengetahui apakah dalam model regresi variabel independen secara parsial berpengaruh signifikan terhadap variabel dependen (Y). maka digunakan Uji t (Gujarati , 1999) dengan hipotesis:

Ho : $\beta 1=0$, artinya variabel jarak tempuh bukan merupakan penjelas yang signifikan terhadap variabel pengembangan wilayah.

$\mathrm{Ha}: \beta 1 \neq 0$, artinya variabel jarak tempuh merupakan penjelas yang signifikan terhadap pengembangan wilayah . 
Ho : $\beta 2=0$, artinya variabel keunggulan komparatif bukan merupakan penjelas yang signifikan terhadap variabel pengembangan wilayah

Ha : $\beta 2 \neq 0$, artinya variabel keunggulan komparatih merupakan penjelas yang signifikan terhadap pengembangan wilayah

Ho : $\beta 2=0$, artinya variabel keunggulan komparatif bukan merupakan penjelas yang signifikan terhadap variabel pengembangan wilayah

Ha : $\beta 2 \neq 0$, artinya variabel keunggulan komparatih merupakan penjelas yang signifikan terhadap pengembangan wilayah

Ho : $\beta 3=0$, artinya variabel integrasi rantai pasokan bukan merupakan penjelas yang signifikan terhadap variabel pengembangan wilayah

Ha : $\beta 3 \neq 0$, artinya variable integrasi rantai pasokan merupakan penjelas yang signifikan terhadap pengembangan wilayah

Untuk uji t hitung digunakan rumus sebagai berikut

$$
t=\frac{\beta i-\beta i}{\operatorname{Se}(\beta i)}
$$

Dengan menggunakan tingkat kesalahan $(\alpha=0.05)$ maka criteria pengujiannya adalah: terima Ho jika thitung $\leq$ $\mathrm{t}_{\text {tabel }}$ dan tolak Ho jika $\mathrm{t}$ hitung $>\mathrm{t}$ tabel.

\section{Kesimpulan dan Saran}

Hasil penelitian dapat disimpulkan bahwa faktorfaktor yang mempengaruhi terjadinya pengembangan wilayah di Keacamatn Binamu, Batang dan ArungkekeKabupaten Jeneponto mencakup variable berupa Variabel Komoditas Unggulan (X1), Variabel Jarak Tempuh Pasokan Komoditas (X2) dan Variabel Komparasi Potensi Komoditas Unggulan (X3). Model regeresi yang diperoleh berdasar pada hasil analisis dan pembahasan, yaitu $\mathrm{Y}=0,186+0,420 \cdot \mathrm{X} 2+0,531 \cdot \mathrm{X} 3(\mathrm{R} 2=$ 0,924). Dalam persamaan tersebut terlihat bahwa faktorfaktor yang paling mempengaruhi adalah Jarak Tempuh Pasokan Produksi Jagung (X2) dan Unggulan Komparatif (X3) di Kabupaten Jeneponto. Adapunnilai R2=0,924 menandakan bahwa variabel-variabel tersebut memiliki pengaruh sebanyak $92,4 \%$ terhadap pengembangan wilayah di Kecamatan Binamu, Batang dan Arungkeke Kabupaten Jeneponto dalam hal pasokan komoditi jagung.

\section{Daftar Pustaka}

Abdurahman, Benjamin. 2005. Pemahaman Dasar Regional Management \& Regional Marketing: Instrumen Strategis Pembangunan Wilayah dan Kota dalam Menghadapi Tantangan Globalisasi dan Implikasi Pelaksanaan Otonomi Daerah. Semarang: Ikatan Ahli Perencana Indonesia (IAP) Jateng.

Alkadri, Muchdie dan Suhandojo. 2001. Tiga Pilar Pengembangan Wilayah: Sumberdaya Alam, Sumberdaya Manusia dan Teknologi. Jakarta: Pusat Pengkajian Kebijakan Teknologi Pengembangan Wilayah. BPPT.

Ambardi, U. M. dan Socia, P., 2002. Pengembangan Wilayah dan Otonomi Daerah, Jakarta: Pusat
Pengkajian Kebijakan Teknologi Pengembangan Wilayah.

Anwar, 2012. Analisis Daya Saing Komoditi Rumput Laut Melalui Pendekatan Policy Aanalysis Matrix (PAM) Di Kabupaten Lombok Timur,p.unram.ac.id/data/2012/ 04/5Anwar.pdf.

Budiharsono. 2002. Teknik Analisis Pembangunan Wilayah Pesisir dan Lautan. Jakarta: Pradnya Paramita

Brata, A.G, 2002. Pengeluaran pemerintah daerah dan konvergensi pendapatan per kapita: Studi Kasus Jawa Tengah (1995/1996-1998/1999).

Choudhury Abud, Abdullahil Azem, Zaheed Halim, 2010, "Effect on Information and Knowledge Sharing on Supply Chain Performance: A Survey Based Approach", JOSCM.

Desembriarto, D, 2000. Konvergensi produk domestik regional bruto per kapita 26 propinsi diIndonesia periode 1977-1997, Tesis Program Studi IESP PPSUGM Yogyakarta.

Elmi, B, 2003. Studi peningkatan ekonomi dan keuangan Kabupaten Lampung Utara, Jurnal Kajian Ekonomi dan Keuangan, vol. 7, no.1, maret, hal. 81-109.

Friedman, John and Allonso. (2008). Regional Economic Development and Planning. Mars. MIT Press.

Gujarati D., 1999. Ekonometrika Dasar Cet. 6, Alih Bahasa Sumarno Zain, Erlangga Jakarta.

Martin, Ronald L 2009. A Study on the Factors of Regional Competitiveness, Cambridge Econometric, University of Cambridge.

Rustiadi E, Saeful Hakim S, Panuju DR, 2011. Perencanaan Pengembangan Wilayah Edisi Ketiga. Jakarta: Crestpent Press Yayasan Obor Indonesia.

Sugiono, Soetomo 2002, Dari Urbanisasi ke Morfologi Kota: Mencari Konsep Pembangunan Tata Ruang Kota Yang Beragam”. Universitas Diponegoro presse, Semarang.

Tarigan, R. 2005. Perencanaan Pembangunan Wilayah, Jakarta: Penerbit Bumi Aksara.

Triutomo, S., 2001. Pengembangan Wilayah Melalui Pembentukan Kawasan Ekonomi Terpadu dalam Tiga Pilar Pengembangan Wilayah, Jakarta: BPPT 